\title{
Autoeroticism: Rethinking Self-Love with Derrida and Irigaray
}

\author{
Ellie Anderson
}

\begin{abstract}
How can I love myself? Who is who in this love? I relate to myself, I affect myself, I am affected by myself. That which affects me is an attribute of mine. But who or what separates the one who loves from the one who is loved? And, if both of these are separated, who or what allows them to come close again? (Irigaray, Ethics 60)
\end{abstract}

In this essay, I argue that autoeroticism is a genuine form of Eros, even when Eros is understood as love for that which is irreducibly other to the self. Drawing on insights from post-structuralism and response ethics, I argue that the autoerotic act involves an irreducible alterity, rather than being enclosed within the independent self-absorption of a sovereign subject figured by traditional views of masturbation. This view of autoeroticism challenges the widely held view, here represented by Levinas, that masturbatory pleasure does not involve genuine alterity and is therefore distinct from the erotic encounter with another being. ${ }^{1}$ On my view, autoeroticism not only concretely illuminates the erotic encounter, but also opens up radical possibilities for refiguring the self as selfothering. An analysis of the alterity involved in autoeroticism therefore informs poststructuralist approaches to the self. I will show that Derrida and Irigaray in particular explore the autoerotic phenomenon of masturbation not as a practice that restores wholeness to the self but as one

\footnotetext{
${ }^{1}$ The idea that masturbation is either distinct from or deficient in relation to the erotic act involving another person has a long tradition in the history of philosophy. For many, including Aquinas, Kant, Rousseau, Nagel, and Solomon, masturbation is a perversion of the natural sex act involving two people. Regardless of moral implications, masturbation is for these thinkers an ontologically deceptive substitute for the truly erotic encounter. In a different context, some feminist thinkers also emphasize the interpersonal character of Eros in order to distinguish it from nefarious forms of autoeroticism, such as the instrumentalizing objectification of women in pornography, which is often used as material for (male) masturbation. See Dworkin, Lorde, O'Neill, and Assiter. Autoeroticism is also a concern for the psychoanalytic tradition and its transformations in contemporary queer theory; see, for instance, Freud, Lacan, Sedgwick, and Bersani.
} 
that instead reveals internal otherness or division. I emphasize that a heterogeneous, divided self is a necessary condition for masturbation: that is, alterity within the self makes the pleasures and joys of self-touching possible.

\section{Erotic Love as Love of Alterity}

The view of Eros that I will take as a starting point is drawn primarily from the post-structuralist tradition of response ethics. Response ethics, which originates in the Levinasian notion that there is a "radical separation between the same and the other," rejects the idea that ethical relations to other beings are premised on similarity, sameness, or knowledge (Levinas, Totality 36). Instead, response ethicists take the ethical relation to other beings to be a relation to others precisely by virtue of their otherness, resisting the subsumption of otherness into sameness. The Other, according to this view, is a being who appears as completely beyond the grasp of the self, or as foreign to oneself. This tradition conceives of ethics as response-ability to the other, thereby disavowing universalizing, rulebased ethical positions in favor of situational responses to other beings (see Oliver). The contention that relations to other beings occur in and through otherness gives rise to a particular view of Eros that I will put forth here, a view that corresponds quite closely to Greek origins of Eros as a desire, yearning, and, at least in Aristotle, irrational excess (Aristotle 150). Eros has a privative character: it exists as a longing for what one cannot fully possess, understand, overcome, or fuse with oneself. As classicist Anne Carson puts it, "The Greek word eros denotes 'want,' 'lack,' 'desire for that which is missing"' (Carson 10). Carson goes on to write: "It is by definition impossible for him to have what he wants if, as soon as it is had, it is no longer wanting. This is more than wordplay. There is a dilemma within eros that has been thought crucial by thinkers from Sappho to the present day" (10). For our purposes here, I will define Eros as the desire, inclination, or pull towards something irreducibly other. It is a form of love that relates to the other in his or her difference from us. That is to say, the defining feature of Eros is precisely the alterity of the one who is loved. Erotic love is an intimacy in distance: what is other is never presented as capable of being possessed, known completely, or fused with oneself. While other forms of love do not necessarily require sameness or similarity, Eros is the kind of love for which this difference is central: it is precisely the other's alterity that is loved in erotic love. This insight, which inflects the Greek conception of Eros with a response ethics twist, does much in the way of explaining why erotic love is never capable of full satisfaction but rather requires a certain lack in order for desire and yearning to persist. As Carson puts it, "Who ever desires what is not gone? No one. The Greeks were clear on this. They invented eros to express it" (11). Absence is required for Eros; even in the greatest intimacy, which 
brings us as close as possible to the presence of the Other, absence is nevertheless operative because what is absent is full knowledge of the subjectivity, self-presence, or position of the other. ${ }^{2}$

Erotic love brings two individuals as close as possible to one another only to reveal their immeasurable distance. On the one hand, knowledge plays an obvious role in romantic relationships. Romantic love grows and deepens through gaining knowledge about the other person. Shared conversations, experiences, time spent with the other person, and learning about the other's life narrative are key in the development of a romantic relationship. This sometimes leads to the illusion that one can have complete knowledge of the other person, unifying with the other in a dream of cognitive fusion. Yet, romantic love reveals that this knowledge is necessarily incomplete. The more one comes to know the other, the more one identifies with the other and is able to anticipate the other's desires, needs, feelings, and thoughts - and yet at the same time, the more one is able to see that one can never live under the other's skin, can never identify completely, and is always capable of surprise in the face of the other. The joy of getting to know another person intimately in erotic love is counterbalanced by the sometimes acutely painful recognition that one can never know that person completely. The more one gets to know another being, the more one sees that that other being is more than one could possibly know. What lovers share through knowledge about each other enriches their bond, but is not its key component. Rather, erotic love is based on a love of what cannot be shared: we love the other for her irreducible difference from us.

This view of erotic love contrasts with conceptions of Eros that foreground fusion with the other, the most famous example being the twohalves model of Aristophanes' myth in Plato's Symposium. Our view of Eros conforms instead to that of Levinas, where:

in the proximity of another the distance is wholly maintained, a distance whose pathos is made up of this proximity and this duality of beings. What is presented as the failure of communication in love in fact constitutes the positive character of the relationship; this absence of the other is precisely his presence qua other. (Levinas, Existence 98-9)

Erotic love is, for Levinas, a proximity without fusion. It is not a love that concerns knowledge of the other, but that pertains instead to the other as ultimately unknowable or mysterious (Time 99). At the same time, this is not to say that there is no truth to the idea of Eros as a fusion between self and other. On my view, Eros may involve a longing for fusion, but this

${ }^{2}$ For Aristotle, desire properly becomes eros only when the lover desires the beloved while the beloved is absent (171). 
longing is by necessity foiled because of the inability to be in the position of the other. Our view is to an extent compatible with the fusion model of erotic love suggested by Plato's Aristophanes inasmuch as he describes erotic love as an intense yearning that one cannot explain: sexual union is not enough to satisfy lovers, because "the soul of every lover longs for something else; his soul cannot say what it is" (Plato 475). What one longs for in erotic love, on Aristophanes' view, is fusion, but it is crucial that the lovers do not have knowledge of that for which they yearn. They are in the dark, so to speak, with respect to the reason for their own passion, and so the dream of fusion is foiled from the start.

Given that we have defined Eros as a desire for that which is irreducibly other, it might appear that the foregoing claims are incompatible with the notion that autoeroticism is a genuine form of Eros. If Eros pertains to love of one who is irreducibly other, then does it not follow that giving oneself pleasure is not erotic? This logic would appear to follow necessarily from a conception of erotic love that involves the alterity of lovers to each other. However, here I will argue that masturbation cannot be so neatly delineated from Eros. It will be the task of this essay to argue that autoeroticism can be considered a genuine form of Eros when joined with a post-structuralist view of the self as selfothering. In fact, I will claim that autoeroticism is necessary in order to experience erotic love for beings besides ourselves. This argument, which will draw on the work of Derrida and Irigaray, will require a troubling of any easy distinction between self and other or sameness and otherness. We will see that sameness is constituted in and through its relationship to what is other to it, and that this is highlighted through the experience of erotic self-touching. While we will preserve the idea that Eros inclines the self towards otherness, we will claim that this otherness is already apparent in what we generally think of as the self. As a result, we will claim that autoeroticism is what I call an auto-hetero-eroticism, playing on Derrida's description of auto-affection as auto-hetero-affection. Finally, we will claim that erotic love for other beings is also a form of auto-heteroeroticism.

Before we turn to these sections of the essay, let us briefly highlight the contrast between Levinas's view of Eros, which is desire for the Other, from jouissance, which is a form of self-enjoyment that for Levinas remains within the egoic domain of the Same. ${ }^{3}$ While we will hold on to the definition of Eros as the desire for the irreducibly other that we drew from Levinasian response ethics, we will take issue with

3 I maintain the French term jouissance, which Alphonso Lingis translates as "enjoyment," because of the connotations of excess and orgasmic pleasure of the French term that I do not think are adequately figured by "enjoyment." 
Levinas's distinction between egoic jouissance and other-directed Eros. We will maintain our Levinasian definition of Eros, but show through Derrida and Irigaray that this definition can be extended to autoeroticism.

For Levinas, autoeroticism is a contradiction in terms. The autoerotic act of masturbation, which I will here take to mean selfstimulation for sexual pleasure, happens within the domain of what Levinas would call the Same inasmuch as it does not involve an immediate relation between oneself and another being. ${ }^{4}$ From his earliest works, Levinas was interested in Eros as a particularly salient form of relation for the encounter with the Other (see Time, and Existence). Eros, for Levinas, is contrary to possession (Totality 265). Erotic love seeks neither to possess nor to join completely with the other. Eros, he writes, "grasps nothing, issues in no concept, does not issue, has neither the subject-object structure nor the I-thou structure. Eros is not accomplished as a subject that fixes an object, nor as a projection, towards the possible. Its movement consists in going beyond the possible" (261). For Eros to "go beyond the possible" suggests that it takes the self beyond what it can know, anticipate, or imagine. This erotic relation to the Other is so important for Levinas that he actually considers it the origin of intersubjectivity. He writes: "Intersubjectivity ... is brought about by Eros" (Existence 98). Eros is what brings one face to face with the Other.

Because we have seen that Eros preserves an irreducible distance between lovers for Levinas, he denies that there can be Eros in the relation to oneself. According to Levinas, the interior life of the self concerns jouissance but not Eros. Jouissance, which Levinas does not only take to indicate sexual pleasure but more generally considers to be the enjoyment that the self takes in its world, whether eating, basking in the sun, or satisfying its needs, is cut off from relation to the Other. Levinas puts forth jouissance as his alternative to intentionality in Husserl: it is the way that the ego comports itself towards and interacts with what appears to its consciousness (Totality 122). Jouissance is characterized by "independence" and "sovereignty" (114). Whereas Levinas considers Eros the origin of intersubjectivity, he describes jouissance as the origin of subjectivity (114). It concerns otherness only insofar as jouissance subsumes what is other into the self: in digestion, for instance, one transforms other material into oneself. It does not concern the other as Other; that is, as infinite, transcendent, irreducible to sameness. Rather, jouissance is entirely without relation to the Other. Levinas writes: "In jouissance I am absolutely for myself. Egoist without reference to the

\footnotetext{
${ }^{4}$ While corresponding to the everyday use of the term in contemporary English, this definition of masturbation as self-stimulation for sexual pleasure is slightly different from its literal definition as stimulation of the genitals with the hand for sexual pleasure, in which the hand(s) can be either those of oneself or another person.
} 
Other, I am alone without solitude, innocently egoist and alone" (134). Giving oneself pleasure through autoeroticism would pertain to jouissance rather than to Eros for Levinas, then, because autoeroticism does not involve an other as Other. He does not grant this irreducible alterity to the self's relation to itself, because this relation happens within the domain of the Same. ${ }^{5}$

\section{Derrida's Auto-Hetero-Eroticism}

The claim that Eros cannot be found at the level of relation to self, but instead requires a comportment towards another being, is one with which Derrida takes issue. For Derrida, any relation to self already bears the trace of alterity within it to such a degree that a Levinasian distinction between jouissance and Eros is untenable. Like Levinas, Derrida agrees that Eros requires a separation or distance between lovers. Derrida states, "This effraction of the other, of what cannot return to self, is the condition of desire" (Touching 282). However, he disagrees with the Levinasian viewpoint that disavows any trace of the Other within the domain of the relation to self. Derrida notes, "According to Levinas there would be no interior difference, no fundamental and autochthonous alterity within the ego," but takes this position to be unsound because the absence of any interior difference would make a relation to the other in principle impossible (Writing 109). Derrida contends that there would be no jouissance without alterity already within the self to make it possible. His arguments in "Violence and Metaphysics" constitute his first sustained version of this critique of Levinas even as they do not pertain specifically to Eros. Here, he takes on Levinas's claim that the 'play of the Same' occurs without reference to the Other, asking, "Without alterity in the same, how could the 'play of the Same' occur, in the sense of playful activity, or of dislocation, in a machine or organic totality which plays or works?" (127) On Derrida's view, the binary Levinas sets up between the play of the Same and the intervention of the Other is self-deconstructing because there could be no play of the Same-no jouissance-without some trace of alterity.

We will first make some brief general comments about the conception of identity and difference in the work of Derrida in order to set up the stakes of his argument before turning specifically to his claims about autoeroticism. Perhaps Derrida's chief insight, reiterated in various

\footnotetext{
${ }^{5}$ While Levinas - partly on the basis of the arguments Derrida makes in "Violence and Metaphysics" that we will mention in the following section-does revise his view of subjectivity in Otherwise than Being in such a way that he grants alterity within the self, his view of jouissance in this later text is not revised to account for internal otherness. Where Levinas speaks of jouissance in Otherwise than Being, it is still in terms of an egoic pleasure of the Same.
} 
forms from the beginning to the end of his career, is that there is a fissure of difference within anything presented as selfsame. For Derrida, sameness or identity is a product of differance, the term that names the differing and deferring movement that at once produces anything as "the same" and forever prevents it from being pure, isolated, or sovereign. ${ }^{6}$ This does not mean that there is no sameness or identity-a common misinterpretation of Derrida's work-but rather that there is no sameness or identity that is free from difference or otherness. ${ }^{7}$ This idea also goes for the self: while Derrida is often associated with the so-called "death of the subject" characteristic of French post-structuralism beginning in the 1960s, he does not in fact deny selfhood or subjectivity. The subject is not independent, autonomous, or self-constituting; rather, it is split open from the start by différance. Derrida argues that selfhood and subjectivity should be considered effects of différance. ${ }^{8}$ As Derrida scholar Peggy Kamuf puts it, "self-relation is possible and interiorizable as an effect only through differing from and deferring of some interior "non-selfness," which Derrida refers to as différance (Kamuf 13). For Derrida, any form of sameness is an effect of repetition: in a Heideggerian spirit, we can say that sameness for Derrida bears an $\mathrm{A}=\mathrm{A}$ structure, meaning that the same is produced as same through its doubling (see Heidegger). ${ }^{9}$ The same produces itself as itself by introducing difference into itself. A key term for describing this conception of sameness as an effect of repetition is auto-affection: as Derrida writes, "Auto-affection constitutes the same (auto) by dividing it" (Grammatology 166). Auto-affection is a form of self-touching that characterizes any experience whatsoever for Derrida, and which is possible only on the basis of division, fissure, or différance. ${ }^{10}$

${ }^{6}$ As Derrida puts it in Voice and Phenomenon: "Must we not say that the concept of pure solitude - and of the monad in the phenomenological sense-is split open by its own origin, by the very condition of self-presence: 'time' rethought beginning from the différance in auto-affection, beginning from the identity of identity and non-identity in the 'same' of the im selben Augenblick?" (59)

${ }^{7}$ Indeed, Derrida affirms sameness as a product of différance to such a degree that he calls différance "a certain inscription of the same" and a "reaffirmation of the same" (Derrida \& Roudinesco 21).

8 Derrida writes: "Subjectivity-like objectivity-is an effect of différance, an effect inscribed in a system of différance" (Positions 28). A similar formulation of this claim, but with respect to Husserl specifically, is found in Voice and Phenomenon: "This movement of différance does not supervene upon a transcendental subject. The movement of différance produces the transcendental subject" (71).

${ }^{9}$ While it is far outside the purview of this essay to pursue these connections in greater detail, it also bears mentioning that this view shares similarities with those of Fichte and Deleuze.

10 "Auto-affection is a universal structure of experience. Every living thing has the potential for auto-affection. And only a being capable of symbolizing, that is to say of 
Crucial for our purposes is the generally ignored fact that one of the first places where Derrida considers auto-affection is precisely in terms of autoeroticism. In fact, it is from autoeroticism that Derrida draws conclusions about auto-affection, or the fissure within the selfsame, as the condition for the possibility of any experience. In Of Grammatology, Derrida takes up Rousseau's remarks about masturbation or "onanism" in the Confessions and the Émile. Derrida explains that, for Rousseau, the autoerotic act is a dangerous perversion or evil supplement to nature. In autoeroticism, one touches oneself by oneself, thereby perverting the purportedly natural sexual relation involving another person. Rousseau views masturbation as a shameful act of sin. Onanism corrupts a self that would otherwise be pure, and is therefore a danger against which one must guard. Auto-eroticism happens alone, and yet is haunted by absent others: most notably, the object of Rousseau's boyhood fantasies. This action, which is solitary and yet accompanied by the mental image of the desired other, corrupts the masturbator both morally and ontologically: autoeroticism introduces otherness within the supposedly pure individual self. Derrida writes: "In affecting oneself from another presence, one adulterates oneself by oneself [on s'altère soi-même]" (153; trans. modified). That is, masturbation on Rousseau's view constitutes an alteration or adulteration of the self that goes against nature, corrupting the self with what is other to it. The act of masturbation is an act of selfothering.

In light of this analysis of Rousseau, Derrida argues that the otherness of the self is at once what makes it possible to give oneself pleasure and what makes it impossible to say that the self, in its own purity and self-presence, is giving itself pleasure. The self gives itself pleasure from the other, as other. The autoerotic act trades on a certain separation or distance between the giver of pleasure and the receiver of it. While giver and receiver are, considered from a certain perspective, the same, Derrida argues that there would be no pleasure if there were no separation between the two. He claims that otherness intervenes in the interstice between the performing of the autoerotic action and the taking pleasure in it, relating to auto-affection generally. He writes: "Within the general structure of auto-affection, within the giving-oneself-a presence or a pleasure [jouissance], the operation of touching-touched welcomes the other in the slight difference that separates doing from suffering [l'agir $d u$ pâtir]" (165; trans. modified). Giving oneself pleasure requires a division within the self insofar as a difference between the giver and receiver of pleasure is required in order for the masturbatory act to be erotic. While Rousseau, of course, finds the masturbatory act deplorable and perverse,

auto-affecting itself, may let itself be affected by the other in general. Auto-affection is the condition of an experience in general" (Grammatology 166; trans. modified). 
Derrida argues that self-othering is in fact what constitutes the self. For Derrida, "this adulteration [altération] does not simply happen to the self"; rather, "it is the self's very origin" (153; trans. modified). Masturbation, then, would indicate not a contingent and therefore avoidable way of being, but rather would indicate the structure necessary not only for giving pleasure to oneself but also for having a self at all. This notion follows clearly from what we laid out above with respect to Derrida's claim that sameness is an effect of différance. The adulteration or alteration of the self that occurs within autoeroticism paradoxically, by bringing otherness into what purported to be pure or separated from otherness, constitutes the self.

The effects of auto-affection proliferate outside of the context of giving oneself masturbatory pleasure. Derrida writes, "sexual autoaffection, that is auto-affection in general, neither begins nor ends with what one thinks can be circumscribed by the name of masturbation" (1545). Erotic self-touching indicates that experience itself can be thought of as auto-affection - or, to use a term that Derrida coins decades after his discussion of Rousseau in Of Grammatology, "auto-hetero-affection" (Touching 180, 292). Inasmuch as auto-affection indicates a fissure of difference in the autos that at the same time constitutes it, the autoaffective is auto-hetero-affective. ${ }^{11}$ Auto-affection is never separable from hetero-affection; the history of philosophy that has striven to overlook this has failed to comprehend the trace of otherness in any auto-affective movement, including that of self-identity.

This line of thinking allows us to think of autoeroticism as autohetero-eroticism. Taking Derrida's discussion of masturbation together with his term 'auto-hetero-affection,' we can coin the term 'auto-heteroeroticism' as a way of figuring what is at work in the autoerotic act. Following what we said earlier about sameness as an effect of différance, the structure of auto-hetero-eroticism is not a disavowal of the autos at work in auto-hetero-eroticism. We are not rejecting the auto- in favor of the hetero-, but rather showing their mutual imbrication. While we have seen that hetero-affection is a necessary component of auto-affection, it bears noting that auto-affection is also a necessary component of heteroaffection. In On Touching, Derrida writes of the necessity of self-touching in order for touching other beings to be possible. He states: "In the 'selftouching-you,' the 'self' is as indispensable as you. A being incapable of touching itself could not bend itself to that which absolutely unfolds it, to the totally other who, as totally other [comme tout autre], inhabits my

${ }^{11}$ As Catherine Malabou puts it in her recent book, Self and Emotional Life, "Derrida does not challenge autoaffection as such - there is an unmovable autoaffective dimension of subjectivity - but he criticizes the way in which philosophers always present it as pure (i.e., as purified of any heteroaffection)" (Johnston \& Malabou 19). 
heart as a stranger" (291). Without auto-affection, there would be no possible relation to that which is other. Without a possible relation to that which is other, there would be no experience. One must always already be in relation to oneself through auto-affection in order to be affected by the other. For erotic love for another being to be possible, one must also be in autoerotic relation to oneself, a notion Derrida draws out of a play on the bivalent French phrase il faut s'aimer, which means both "to love oneself" and "to love each other." He writes: "It is necessary to love oneself, each other [il faut s'aimer], says every 'I love you,' and without this (impossible) auto-affection, without the reflected experience of impossible auto-affection, without the ordeal of the possibility of this impossibility, there would be no love" (291). There is no love for another without selflove. ${ }^{12}$ If autoeroticism is always auto-hetero-erotic, so too is erotic love for another being necessarily autoerotic - a notion that, we will see, Irigaray also affirms.

To say that the autos of autoeroticism is interwoven with the heteros is not to say that there is a monolithic, singular form of otherness that is introduced into sameness. A crucial consequence of Derrida's writings on différance is the affirmation of a multiplicity of differences, or traces of differences, that cannot be absolutized or collected under the rubric of a single difference, writ large. ${ }^{13}$ Rather than distinguishing "pure auto-affection of the body proper" from hetero-affection, Derrida wonders: "shouldn't one rather distinguish between several types of autohetero-affection without any pure, properly pure, immediate, intuitive, living, and psychical auto-affection at all?" (180) The otherness that comes to intervene on the purportedly pure self of autoeroticism is not a self-present, pure, or singular otherness itself-for this conception would be based on the very metaphysical view that took sameness to be rigidly separate from otherness to begin in the first place.

One consequence of this idea, which will be pursued in the next section in the work of Irigaray, is that the self-other structure of autoeroticism is not merely dual. We may say that the self is doubled, but that the doubling does not stop here: the self is in principle affected by a tripling, and by a continual multiplication. If the self is not singular, but already double, then it is also more than double. As Derrida states in On Touching:

The self-touching-you remains incalculable. It weighs, but thinking it exceeds its calculation. It is neither one (monadic), a single one,

\footnotetext{
${ }^{12}$ This view traces at least as far back as Aristotle, who claims in the Nicomachean Ethics that philautia is necessary for philia.

13 Although we will not pursue this idea here, Derrida's disavowal of otherness as absolute or infinite marks a crucial difference from Levinas.
} 
a unique self-touching-oneself, nor the double, symmetrical, and above all immediate relation of a reciprocal self-touching-oneanother whose impersonal law could be uttered in the third person. (281)

If self-touching reveals the self to be doubled into self and other, it does not leave these terms intact: the terms of sameness and difference must be thought otherwise than through traditional metaphysical connotations of great kinds, genres, or types of being. Differrance allows us to think difference as a proliferation of traces. This conception of difference opens the self up to incalculability: it is not merely as if in describing autoeroticism as an auto-hetero-eroticism, one is lodging a singular "otherness" within an otherwise whole, present, or substantial self. Rather, autoeroticism reveals that the self exceeds calculation, the doubling of the self being more than a doubling, and the self-touching subject unable to be considered as a revelation of an "impersonal law" that could be perceived from an idealized or objective outside. We will see in the following section how the incalculability of the self figured by autoeroticism is further illuminated by the work of Irigaray, who affirms what I am calling auto-hetero-eroticism while figuring it vividly in terms of the feminine self-touching overlooked by patriarchal norms.

\section{Love of Self and Love of Other in Irigaray}

Like Derrida, Irigaray disrupts received narratives about masturbation as a solitary, independent, even selfish action cut off from alterity. While Irigaray does grant that some ways of considering autoeroticism do fall into this traditional conception of masturbation, she associates it with the oppressive patriarchal schema that has denied the alternative possibilities of feminine desire, which can figure an autoeroticism that does not remain trapped in an economy of the Same. That is, Irigaray is concerned with a feminist project of distinguishing the self-othering practice of Eros as it has been co-opted by patriarchy from a kind of erotic self-othering that can lead to new frontiers of love of other beings and love of self. Through her evocative descriptions of erotic relations, Irigaray affirms the irreducible difference and alterity of the other and shows that it is revealed through the experiences of erotic love. She claims, "Not in me but in our difference lies the abyss. We can never be sure of bridging the gap between us. But that is our adventure. Without this peril there is no us. If you turn it into a guarantee, you separate us" (Passions 28). Thus, Irigaray maintains the primary insight we have drawn from the Levinasian conception of Eros: the requirement that the erotic relation is a matter of 
loving the other in his or her alterity. ${ }^{14}$ At the same time, however, she claims that there is a "love of self" that contrasts with a masturbatory or egoic love that remains caught in self-absorption. Irigaray's erotic love of self demonstrates the double relation of self to self that provides the condition for loving another. Thus, Irigaray's work represents a rigorous and creative series of attempts to explore the nature of an erotic relation to the other that maintains the other's difference, as well as bringing into focus the alterity to self constitutive of a way of being that does not fall prey to the destructive illusions of the transcendent metaphysical subject of the patriarchal schema. As Lynne Huffer puts it, Irigaray invites a "masturbatory ethics of love" (Huffer 127).

Irigaray imaginatively plays off the feminine "lips" in order to demonstrate the autoerotic nature of selfhood as figured by the feminine. ${ }^{15}$ As opposed to the independent, autonomous individual of the phallic imaginary that has been bolstered throughout the history of philosophy, Irigaray shows that the interdependent and self-othering subject is figured by the image of the lips. For Irigaray, the lips are autoerotic inasmuch as they indicate a body that is doubled and self-touching, selfsame only in its self-differing. There is no sameness for woman on Irigaray's view, if sameness is taken to be cut off from alterity: woman is always already self-othering. This is indicated even in the title of her major work This Sex Which is Not One, where Irigaray suggests that woman is not "one" in the dual sense of being "less than one" by the denial of her subjectivity in patriarchy and of being "more than one" by her association with the dual lips. To be "more than one" is to be plural within oneself, near to oneself. She writes:

Woman always remains several, but she is kept from dispersion because the other is already within her and is autoerotically familiar to her. Which is not to say that she appropriates the other for herself, that she reduces it to her own property. Ownership and property are doubtless quite foreign to the feminine. At least sexually. But not nearness. Nearness so pronounced that it makes all discrimination of identity, and thus all forms of property,

\footnotetext{
${ }^{14}$ At the same time, Irigaray offers one of the best-known feminist critiques of Levinas's view of Eros (see Ethics). While an analysis of this falls outside the scope of this essay, it is worth pointing out that Irigaray maintains Levinas's conception of Eros as a comportment to the irreducibly other while disavowing the problematic gendered dimensions of this conception in Levinas's own work.

15 I take the "lips" in Irigaray to be a way of symbolically figuring alternatives to prevailing masculine philosophical conceptions, and therefore do not take her anatomical imagery to correspond literally to the biological female sex. Thus, I do not consider Irigaray - at least in the period of her writings from which I am drawing - to be an essentialist or to be incompatible with queer feminisms. In this vein, I take my cue from Huffer's arguments on the compatibility of Irigaray and queer theory.
} 
impossible. Woman derives pleasure from what is so near that she cannot have it, nor have herself. (Irigaray, Sex 31)

Irigaray articulates here an Eros that offers proximity without possession. This formulation, while quite close to the Levinasian definition of Eros with which we began this essay, exceeds Levinas in situating the erotic on the level of the relation to self. This not only corresponds with the Derridean view of autoeroticism that we laid out earlier, but also adds a significant component to that view by describing it in terms of feminine desire, a component lacking in Derrida's description of exclusively male masturbation in Of Grammatology.

The lips are a curious place to locate woman's autoeroticism, because they are not generally associated with pleasure. Rather, the erogenous zones of the female genitalia are typically considered to be the clitoris and the vagina, a notion that Irigaray traces back to Freud (23). The clitoris is perceived as an inferior version of the male penis, while the vagina is seen to be a sheath or hole for penetration. In contrast with this view, which either relegates feminine pleasure to a pale imitation of masculine pleasure in the clitoris or conceives it as its passive obverse in the vagina, Irigaray reclaims the lips for woman's autoeroticism. She writes that, by virtue of the lips, "Woman 'touches herself" all the time, and moreover no one can forbid her to do so, for her genitals are formed of two lips in continuous contact" (24). The injunctions against erotic selftouching that we saw lead to much guilt in Rousseau do not pertain to woman, Irigaray suggests, because she is always already touching herself. Irigaray contrasts this with the male form of masturbation, in which "He can only touch himself from the outside (Passions 15). For her, this absence of primary self-touching leads to the male yearning to "recapture the whole sensation of the inside of a body," frequently resulting in the oppressive use and possession of women (15). It is only when we reassess these oppressive tendencies through the symbol of the lips that we will be capable of conceiving of Eros, autoeroticism, and the self who relates to others and to itself according to a different economy.

A crucial aspect of this "different economy" for which an Irigarayan love of self would allow is its incalculability, a notion that we have seen Derrida affirm as well. ${ }^{16}$ Irigaray writes of woman, "within herself, she is already two - but not divisible into one(s) - that caress each other" (Sex 24). While the lips are a figure of twoness, they are also more and less than two, because they cannot be considered as separable from each other, as two individual entities that come together. To consider them in this manner would be to fall prey to a fallacious metaphysics that takes

${ }^{16}$ Irigaray also claims that the erotic relation between lovers is incalculable (see Passions 58 and Sex 31). 
the world to be made up of separate and mutually independent entities, a metaphysics that is itself based on masculine dreams of separation and individualism. The lips encourage us to consider identities otherwise than on the basis of this schema. They encourage a different thinking of the metaphysical binaries of presence/absence, sameness/difference, self/other that does not presume that terms are absolutely independent of, let alone opposed to, each other. In this way, Derrida and Irigaray share a phenomenological and antifoundational interest in disrupting binaries, attending instead to an identity based on the doubling of differences.

Irigaray also relates this disruption of binaries to the question of calculation: the doubling of the self does not mean that we have merely traded a conception of the self as singular for a conception of the self as doubled (self-other). Rather, she writes: "I've never known how to count. Up to you. In their calculations, we make two. Really, two? Doesn't that make you laugh? An odd sort of two. And yet not one. Especially not one. Let's leave one to them: their oneness, with its prerogatives, its domination, its solipsism: like the sun's" (Sex 207). Not only do the lips call into question the solipsism of the one, but also trouble the stability of the two. Once the presumptions of independent selfhood have been disrupted, the idea of merely adding to this schema by making such a self double reveal themselves to be woefully misguided. In the face of such a conception, Irigaray laughs. In an Irigarayan love of self, "Neither the subject nor the self is fixed in its position or its given" (Ethics 59). Rather, this love of self is fluid, mobile, and self-othering in such a manner that the proliferation of differences prevents any stable calculability of the two.

An advantage that this account has over Derrida's is that Irigaray provides more specific analyses of the way that social structures overdetermine the ways that we think about self-othering: particularly, the phallogocentric schema of patriarchy 'others' feminine subjects in an oppressive manner that is distinct from the self-othering of the lips that she describes. While I do not necessarily think that Derrida's account of autohetero-eroticism is incompatible with an analysis of modes of oppression, it is evident that he does not undertake an analysis of its gendered dimensions and the oppressive history accompanying them. Irigaray, on the other hand, argues that is it "assuredly necessary" to take a "long detour" through the analysis of oppression in order to be able to grasp the liberatory possibilities of autoeroticism suggested by the lips (Sex 31). Woman has traditionally been denied the power even to be alone, and denied the kind of independence or subjectivity that would even allow for a conception of masturbation as an enclosed practice within the sphere of sameness (Passions 51). She states: "The love of self among women, in the feminine, is very hard to establish" (Ethics 101). The phallogocentric economy has boxed woman into a literal and figurative home mediated by the presence of man and failed to register feminine desire as such. As a 
result, it takes considerable imaginative work even to be able to envision a properly feminine autoeroticism. ${ }^{17}$ One of the philosophical tasks that Irigaray takes on, through her evocations of the lips, is the task of constructing symbols for a feminine love of self.

This love of self would be in contrast with the patriarchal form of masculine self-love that has tended to reduce, deny, or use otherness in the service of a purportedly independent self. The patriarchal form of self-love denies otherness within the self, whether through a traditional independent self of the metaphysical subject or through the Levinasian contention that the realm of self-relation is foreign to the Other. Irigaray writes:

Love of self represents an enigma, an impossibility, sometimes a taboo. Often, in this era of sexual subjectivism, all that remains of love of self is a kind of masturbation, certain modes of pleasure and jouissance. But love? This question seems to be much more difficult and is not necessarily to be confused with questions of pleasure or of jouissance. Love of self is a question asked of eros, of agape, of eroticism, of death (60).

The love of self that Irigaray is describing cannot merely be figured as a Levinasian jouissance, but is instead genuinely erotic in nature. It is not "masturbation" in the sense in which the term is usually taken, because, as erotic, it is properly auto-hetero-erotic. A transvaluation of the love of self that takes on the erotic self-touching implied by the lips vividly figures both feminine desire and the post-structuralist self that both Irigaray and Derrida aim to register.

Recall that, in our discussion of Derrida, we argued that there was a certain affirmation of the autos that generally goes unnoticed in his work. We declaimed the idea that Derrida shows a preference for the hetero- and a rejection of the auto- and showed instead the mutual imbrication of the two. This is also the case with Irigaray. On her view, there is "no love of other without love of same" (104). The erotic love of self that she presents is necessary in order for one to be able to love other beings. Because, on her view, love of self has been distorted through patriarchy's denial of desire to women, so too has the love of other beings. A "long detour" through patriarchy is necessary not only for individuals to reclaim autoeroticism, but also to be capable of intersubjective erotic love. Moreover, it is worth briefly mentioning that this necessity of "love of

\footnotetext{
${ }^{17}$ In this vein, masturbation was seen as a liberatory site for women to reclaim their own sexual desire among second-wave feminists, as is evident in Betty Dodson's classic Sex for One. By asserting their own sexual desire through masturbation, second-wave feminists sought to achieve an agential subjectivity previously denied to them. This was linked with what subsequent feminists, notably Irigaray, would then critique as the implicitly masculinist dream of the authentic, agential, independent, and sovereign subject.
} 
Same," on my view, helps to dispel the specter of heteronormativity that has long been associated with Irigaray's work (see Huffer). As Derrida has been aligned with a preference for difference and otherness that has obscured his affirmation of sameness, so too has Irigaray been aligned with a preference for opposing the two sexes in a manner that would apparently overlook homoerotic and queer desire. However, Irigaray's remarks on the love of self and love of same clarify that, for her, even the self or same is irreducibly other to itself and engaged in genuine erotic relation. This means also that we may reconsider her claims about the oppositionality of the sexes in light of the reaffirmation of autoerotic and homoerotic desire that she also opens up, even as exploring this notion fully is beyond the scope of this essay.

To rethink self-love with Derrida and Irigaray means to rethink autoeroticism as auto-hetero-eroticism. On my view, the masturbatory act involves irreducible otherness such that one cannot rigorously distinguish it from erotic love for another being. This contention has been made possible by the post-structuralist views of the self offered by Derrida and Irigaray, which figure sameness as marked, and even constituted by, difference. These views allow us to hold on to the insight from response ethics that holds Eros to be a desire for that which is other in the sense of being resistant to knowledge, possession, or the accomplishment of fusion between lovers. Yet, they enrich this insight from Levinasian response ethics by revealing that this desire for the irreducibly other already holds in the relation to self. Their views allow us to consider that autoeroticism is not a pseudo-form of Eros, even if we take Eros to be a relation to irreducible otherness. It follows from the post-structuralist views of the self that Derrida and Irigaray offer that autoeroticism is auto-heteroeroticism, and that it therefore expresses an impassioned desire for connection with that which is beyond understanding, possession, or control.

\section{Works Cited}

Assiter, Alison. Autonomy and Pornography, in Feminist Perspectives in Philosophy, ed. Morwenna Griffiths and Margaret Whitford. London: Palgrave Macmillan, 1988. pp. 58-71.

ARISTOTLE. Nicomachean Ethics. Trans. Roger Crisp. Cambridge: Cambridge University Press, 2004.

AQuinas, St. Thomas. Summa Theologiae. Cambridge: Blackfriars, 196476. 
BersANI, Leo. "'Ardent Masturbation' (Descartes, Freud, Proust, et al.)," in Thoughts and Things. Chicago: University of Chicago Press, 2015, pp. 37-57.

CARson, Anne. Eros the Bittersweet. Princeton: Princeton University Press, 1986.

DERRIDA, Jacques. Of Grammatology. Trans. Gayatri Chakravorty Spivak. Baltimore: Johns Hopkins University Press, 1976.

-. On Touching_Jean-Luc Nancy. Trans. Christine Irizarry. Stanford: Stanford University Press, 2005.

- Positions. Trans. Alan Bass and Christopher Norris. London: Continuum, 2002.

-. Writing and Difference. Translated by Alan Bass. Chicago: University of Chicago Press, 1978.

-. Voice and Phenomenon: Introduction to the Problem of the Sign in Husserl's Phenomenology. Trans. Leonard Lawlor. Evanston, IL: Northwestern University Press, 2011.

DERrIDA, Jacques, and Elisabeth RoudinESCO. For What Tomorrow...A Dialogue. Trans. Jeff Fort. Stanford: Stanford University Press, 2004.

Dodson, Betty. Sex for One: The Joy of Self-Loving. New York: Three Rivers Press, 1974.

Dworkin, Andrea. Pornography: Men Possessing Women. New York: Penguin Books, 1981.

FREUD, Sigmund. "On Narcissism," in The Standard Edition of the Complete Psychological Works of Sigmund Freud, Volume XIV, trans. and ed. James Strachey. London: Hogarth, 1953-74. pp. 67-102.

HeIDEGGER, Martin. Identity and Difference. Trans. Joan Stambaugh. New York: Harper \& Row, 1969.

HufFer, Lynne. Are The Lips a Grave? A Queer Feminist on the Ethics of Sex. New York: Columbia University Press, 2013.

IrIGARAY, Luce. Elemental Passions. Trans. Joanne Collie and Judith Still. New York and London: Routledge, 1992.

-. An Ethics of Sexual Difference. Trans. Carolyn Burke and Gillian C. Gill. Ithaca: Cornell University Press, 1993.

-. This Sex which is Not One. Trans. Catherine Porter with Carolyn Burke. Ithaca: Cornell University Press, 1985.

Johnston, Adrian, and Catherine Malabou. Self and Emotional Life: Philosophy, Psychoanalysis, and Neuroscience. New York: Columbia University Press, 2013. 
Kamuf, Peggy. To Follow: The Wake of Jacques Derrida. Edinburgh: Edinburgh University Press, 2010.

KANT, Immanuel. The Metaphysics of Morals. Trans. and ed. Mary Gregor. Cambridge: Cambridge University Press, 1996.

LeVINAS, Emmanuel. Existence and Existents. Trans. Alphonso Lingis. Pittsburgh: Kluwer Academic Publishers, 1978.

-. Otherwise Than Being: Or Beyond Essence. Trans. Alphonso Lingis. Pittsburgh: Duquesne University Press, 1998.

-. Time and the Other. Trans. Richard A. Cohen. Pittsburgh: Duquesne University Press, 1990.

-. Totality and Infinity: An Essay on Exteriority. Trans. Alphonso Lingis. Pittsburgh: Duquesne University Press, 1969.

LORDE, Audre. "The Uses of the Erotic," in Sister Outsider: Essays and Speeches by Audre Lorde. Freedom, CA: The Crossing Press, 2007. pp. 53-59.

OLIVER, Kelly. Witnessing: Beyond Recognition. Minneapolis and London: University of Minnesota Press, 2001.

O'NeILL, Eileen. "(Re)presentations of Eros: Exploring Female Sexual Agency," in Gender/body/knowledge: Feminist Reconstructions of Being and Knowing, ed. Alison M. Jaggar and Susan R. Bordo. New Brunswick: Rutgers University Press, 1990.

Plato. Complete Works. Ed. John M. Cooper with D.S. Hutchinson. Indianapolis and Cambridge: Hackett Publishing Company, 1997.

Rousseau, Jean-Jacques. Emile or On Education. Trans. Allan Bloom. New York: Basic Books, 1979.

SEDGWICK, Eve Kosofsky. "Jane Austen and the Masturbating Girl," in Critical Inquiry 17 (Summer 1991).

Solomon, Robert. "Sexual Paradigms," in The Philosophy of Sex: Contemporary Readings, Fourth Edition, ed. Alan Soble. Oxford: Rowman \& Littlefield, 2002. pp. 21-30.

NAGEL, Thomas. "Sexual Perversion," in The Philosophy of Sex: Contemporary Readings, Fourth Edition, ed. Alan Soble. Oxford: Rowman \& Littlefield, 2002. pp. 9-20. 